\title{
Monitoring of total body water to examine the progress of acclimatization of runners at varying altitudes
}

\author{
Miroslav Semerád, Pavel Červinka, Václav Bunc
}

Faculty of Physical Education and Sport, Charles University, Prague, Czech Republic

*Corresponding author: mira.semerad@email.cz

\begin{abstract}
The purpose of our pilot study was to find out if total body water (TBW) changes could objectively modify the course of adaptation during training for elite runners at different altitudes. The aim of this pilot study is to summarize the indication of the progress of acclimatization at high altitudes (1000-2700 meters above sea level) during alpine conditioning. In three training camps at various altitudes the TBW of elite runners $(F=3, M=1 ; n=4 ;$ age $23 \pm 0.9)$ was monitored, in order to check the progress of acclimatization. We used BIA measurement methods (Bodystat 1500) at different high altitude running camps at the Czech Republic, Morocco and Ethiopia. Changes in TBW were used to check the progress of acclimatization. We discovered that the retention peaks of TBW corresponded with critical days ( $p \leq 0.04$; Cohen's $d)$. The highest measured increases of TBW at an altitude of $1000 \mathrm{~m}$ were for runner 1, 1.7 litres and for runner 2, 2.1 litres with retention peaks for both occurring on the 5 th day. At an altitude of $1770 \mathrm{~m}$ runner 1 reached an increase of TBW of 6.3 litres, with a retention peak on the 11th day, and runner 3 had an increase of 5.1 litres with a peak on the 8th day. In the acclimatization phase we found two critical periods, from the 4th-6th day, and after the 10th-12th day. For runner 4 in altitude 2700m who completed the camp at a higher altitude, the situation is more complicated because there were fluctuations of the content of TBW in the range of 1.25 litres, with the highest depression on the 5 th and then again an unsettled rise and reaching a maximum on the 12 th, when she nearly returned to the initial value. Detected retention peaks reflected different levels of altitude (5th-12th days).We can conclude that the measuring of changes in TBW during camps at higher altitudes may be one of the biomarkers during acclimatization to altitude.
\end{abstract}

\section{KEYWORDS}

acclimatization; high altitude; total body water (TBW); bioelectrical impedance (BIA); retention peak; elite runners

DOI

https://doi.org/10.14712/23366052.2017.9

(c) 2017 The Authors. This is an open-access article distributed under the terms of the Creative Commons Attribution License (http://creativecommons.org/licenses/by/4.0), which permits unrestricted use, distribution, and reproduction in any medium, provided the original author and source are credited. 


\section{INTRODUCTION}

Preparation in a high altitude environment is an intensive option of endurance training (Neumann et al., 2000). The positive effect of altitude training is attributed to the changed physical conditions of the atmosphere, especially to the lower partial pressure of oxygen, which leads to stimulation of the entire system of processes in the organism involved with oxygen transportation. The main benefits of adaptation are an increase in red blood cell mass and in oxygen transportation capacity (Noakes, 2003; Alonso, 2004; Arrese et al., 2005; Legrand, 2005; Lungby et al., 2012). Since physical training in the mountains plays an important role in the overall preparation of elite male and female endurance athletes, this pilot study considers the possibility of monitoring acclimatization to high altitude training through changes in TBW. We assume that the conduct and completion of acclimatization at various levels of higher altitudes could be indicated by means of TBW and also that the higher the altitude, the greater the number of days required to reach the retention peak of TBW.

In general, the literature agrees that the ideal conditions are provided by repeated stays of between 21-28 days in length at an altitude of 1800-2200 meters above sea level. Key factors influencing the organism and the training process at high altitudes are: decreasing barometric air pressure, decreasing partial pressure of oxygen $\left(\mathrm{pO}_{2}\right)$, decreasing air temperature (declining by about $1^{\circ} \mathrm{C}$ for every $150 \mathrm{~m}$ of increased altitude), decreasing humidity, and increasing radiation (ultraviolet radiation increases by $20-30 \%$ for every $1000 \mathrm{~m}$ (Basset \& Howley, 2000; Katyama et al., 2003; Gore et al., 2001; Green et al., 2000; Levine et al., 2005; Morrison \& Cooper, 2006; Neumann et al., 2000). The process of acclimatization at higher altitudes depends on the following factors: training level before arrival, physical condition, health and mental stability, altitude of the stay, altitude of personal workout, length of stay, volume and intensity of training load during stay, season and stage of preparation within the framework of the annual macrocycle, and drinking and dietary régime (Noakes, 2003; Green et al., 2000; Bragada, 2010).

An important factor in altitude training is also played by the selection of the location and the frequency of repeated visits. When the length of stay is three weeks or longer, it can be distinguished into three basic phases of the acclimation process accommodation, adaptation and acclimatization (Bragada et al., 2010; Noakes, 2003; Wilber, 2004; Billat et al., 2003; Suchý et al., 2012).

The classification of altitudes from the perspective of sports training has not been clearly settled. According to most authors (Wilber, 2004; Noakes, 2003; Gore et al., 2001) they should be broken down as follows:

$\begin{array}{ll}\text { Low } & >800 \mathrm{~m} \text { above sea level } \\ \text { Medium } & 800-1500 \mathrm{~m} \text { above sea level } \\ \text { Higher } & 1500-3000 \mathrm{~m} \text { above sea level } \\ \text { High } & <3000 \mathrm{~m} \text { above sea level }\end{array}$

The basis for successful training at high altitude is the course of acclimatization. Due to the course of acclimatization it is good to obtain objective indicators. The time to reach full acclimatization is in the range 5th to the15th day, according to the classification of altitude. The process is individual and can be monitored by objective parameters including $\mathrm{HR}, \mathrm{VO}_{2 \max }$, Lactate, Urea in blood serum, Hemoglobin level, 
Hematocrit level, etc. (Noakes, 2003; Wilber, 2004; Green et al., 2000; Neumann et al., 2005; Levine et al., 2005).

Altitude training is accompanied by hyperventilation, resulting from the higher proportion of anaerobic energy requirements, leading to increased acidosis in endurance athletes (Julian, 2003; Lungby et al., 2012). In addition, fluids are lost through sweating, and hyperventilation must be checked (Billat et al., 2003; Sherry et al., 1998; Neumann et al., 2005). This can lead to disruption of the electrical conditions on the muscle membrane during muscle activity. The result is a disruption of muscle contraction (Malina et al., 2004; Weineck, 1998). An increased proportion of anaerobic coverage of energy requirements in training, partly as a result of hyperventilation, partly as a result of the intensity of the applied load - deepening acidosis - is reflected in the recovery stage (Julian, 2003; Katyama et al., 2003; Lungby et al., 2012).

A number of very valuable findings on the progress of acclimatization can be obtained from evaluation during recovery, especially the rate of return of function parameters to sleep or in initial values. Significant information can be gained from monitoring and evaluation of the amount of TBW, which is especially sensitive to changes in volume of training load (Legrand, 2005; Gore et al., 2001; Bunc, 2016). From the perspective of parameter selection and load evaluation, it could be that TBW (together with some biochemical and physiological parameters) appears as a useful biomarker for everyday measurement (Morrison, 2006).

One of the objectives of the training process is to compile an intervention programme that would operate on the organism as efficiently as possible in terms of the development of physical performance. As a part of this programme a large number of changes take place that allow us during the regular monitoring to effectively assess the quality of interventions. One possibility is the monitoring of selected variables of body composition and their changes (Bunc, 2012). Current methods of assessing body composition allow us to evaluate not only the total amount of body fat and fat-free mass, but also to evaluate the 'quality' of muscle mass. TBW includes any water presented in the body (Seunghoon, 2001). Normally the amount of TBW ranges between $60-70 \%$ of body weight depending on age and sex (Deurenberg et al., 2002). One of the main tasks of dietary strategies during mountain training is to minimize dehydration and, together with the intervention programme, to contribute to accelerating the process of adaptation (Legrand, 2005; Levine et al., 2005; Lungby et al., 2012).

Staying at higher altitude is accompanied with increased ventilation and thus greater loss of body water. For successful acclimatization, fluid intake is essential, together with the monitoring of its impact on the current status of the individual. For this purpose it is possible to use tracking of TBW in the known fluid intake (Bunc, 2016). The measurement of TBW is possible due to the development of technologies that are practicable even in field conditions. A suitable method is the use of whole-body bioimpedance analysis, which as a basic quantity measures volumes of bodily fluids - water. A mono-frequency device operating at a frequency of $50 \mathrm{KHz}$ is able to determine the amount of TBW (Sheunghoon, 2001). A quality drinking regime includes adequate fluid intake, which is recommended at around 4 litres per day, because in mountain conditions it is easier to become dehydrated. Fluid loss can occur due to insufficient fluid intake, urination and increased ventilation (Bunc, 2016). The acclimatization process does not proceed smoothly, but usually progresses in several stages. Custom- 
ary crisis days are the 2nd (caused by travel), the 9th (when the intensity of crisis is defined as 'bad mood') and the 15th (when a deeper crisis might be expected, due to depression) (Neumann et al. 2005). The "crisis-depression performance" and fatigue can usually be seen on the 4th-6th and 10th-12th days (Billat et al., 2003; Lungby et al., 2012). The course of acclimatization cannot be accelerated, on the other hand, by not respecting the individual specific reaction of the organism to various contents of the intervention programme. Disregard of the recommendations for acclimatization can disrupt the speed and quality of acclimatization, and can also lead to overload. In the opinion of some experts, assessments during adaptation to high altitude may be indicated by changes in body composition parameters (Lungby et al., 2012; Green et al., 2000).

\section{MATERIAL AND METHODS}

\section{Participants}

Participants in the study included three members of the Czech national team competing at international competitions, and another runner who was a medalist at the national championship $(M=1),(F=3),(n=4)$. The physical and performance characteristics of subjects are given in Table 1 below. The locations of the training camps were selected according to the experience and expertise of the personal trainers, in agreement with the Czech Republic head coach of running and the head coach of the Czech athletics federation. The decision to prepare at different altitudes and lengths of stay corresponded to the normal practice and experience of national coaches. The focus and content of the camps met the requirements of the phases of preparation and specialization of the runners.

\section{Instrumentation}

The camps were gradually organized in the following locations and altitudes: CZECH REPUBLIC (Šumava, October, altitude 1000m above sea level), MOROCCO (Ifrane, February, altitude 1770m above sea level), ETHIOPIA (Sululta, December, altitude $2750 \mathrm{~m}$ above sea level). We evaluated the results in terms of effect size and consequently of statistical significance. We found statistical significance at the level of $\mathrm{p} \leq 0.04$. We used Cohen's $\mathrm{d}$ for evaluating the effect size for finding the fraction of variability between participants. The commonly used evaluation of the coefficient size $d$ is as follows: trivial (0-0.19), small (0.20-0.49), medium (0.50-0.79), and large (0.80 and greater) (Cohen, 1992). For non-homogeneity and low number of participants in the study, we did not detect deviations between male $(n=1)$ and female $(n=3)$. Runner $1(F)$ attended camps in the Czech Republic and Morocco, runner $2(\mathrm{~F})$ attended camp in the Czech Republic, runner $3(\mathrm{M})$ attended camp in Morocco and runner $4(\mathrm{~F})$ attended camp in Ethiopia.

\section{PROCEDURES}

Measurement of TBW was carried out at 08.00 under standardized conditions, on an empty stomach and after drinking about 2 ounces of water. During the day drinking habits were checked and controlled. The personal trainer noted all quantities of fluids 
Table 1 Selected physical and performance characteristics of participants

\begin{tabular}{|c|c|c|c|c|c|c|c|}
\hline Runner & $\begin{array}{l}\text { Age } \\
\text { (year) }\end{array}$ & $\begin{array}{l}\text { Height } \\
(\mathrm{cm})\end{array}$ & $\begin{array}{l}\text { Weight } \\
\text { (kg) }\end{array}$ & $\begin{array}{c}\text { BMI } \\
\left(\mathbf{k g ~ m}^{2}\right)\end{array}$ & Gender & $\begin{array}{l}\text { Time of training } \\
\text { (years) }\end{array}$ & $\begin{array}{l}\text { Personal best } \\
\text { (min) }\end{array}$ \\
\hline 1 & 23 & 171 & 55.0 & 18.9 & $\mathrm{~F}$ & 4 & $36: 17(10 \mathrm{~km})$ \\
\hline 2 & 22 & 163 & 50.5 & 19.0 & $\mathrm{~F}$ & 5 & $4: 20,07(1500 \mathrm{~m})$ \\
\hline 3 & 23 & 180 & 61.5 & 19.1 & $M$ & 2 & $31: 22(10 \mathrm{~km})$ \\
\hline 4 & 23 & 170 & 52.0 & 18.5 & $\mathrm{~F}$ & 6 & $15: 35(5 \mathrm{~km})$ \\
\hline
\end{tabular}

received. Changes in TBW were monitored using bioelectrical impedance analysis (Bodystat ${ }^{\circ} 1500$, Data Input, Darmstadt, Germany). The mono-frequency Bodystat 1500 (operating at a frequency of $50 \mathrm{kHz}$ ) was used to measure TBW. The advantages of this device include: cost, easy transportation, safety and simplicity of operation, and the ability to do field measurements. For the evaluation of the relation to physical load, the training programme was divided into aerobic, mixed and anaerobic zones by running speed (according to individual speed zones) and exercise-induced lactate levels (Lactate Scout+, Amount of lactate, $\mathrm{mmol} / \mathrm{l}$ ). In addition, the corresponding intensity was in the energy zones controlled by continuous measurement, using the Garmin Forerunner sport testers (HR). As a criterion of completion of acclimatization we set the achievement of peak retention of TBW.

Owing to the relatively small sample size $(n=4)$ data collection was carried out every day. From daily readings we retrospectively investigated the conduct of TBW and then compared the data with expert information on critical days and during the acclimatization (Noakes, 2003). The data were evaluated by effect size as trivial (0-0.19), small (0.20-0.49), medium ( $0.50-0.79)$ and large ( 0.80 and greater) (Cohen, 1992). Consistent with the expert literature (Noakes, 2003; Lungby et al., 2012; Bunc, 2016), we considered changes of TBW \pm 0.1 litre/day.

\section{ETHICAL STATEMENT}

Participants in the study were elite Czech runners $(n=4)$ in high altitude preparation and using standard training methods and approaches within their training. The participants were informed of the methods and all the measurement procedures, including the risks, and also about the possibility of further usage of the measured data. Each participant of the study signed an informed consent form, agreeing to the publication of the obtained data, and the four informed consent forms were approved by the Ethics Committee of the Faculty of Sport and Physical Education of Charles University.

\section{RESULTS}

The pattern of change in TBW varied during the different training camps (figures 1-3). The first four measurements found water retention in the first stage of each training camp regardless of the altitude, with differences between individuals and training camp sites in the size and day of reaching peak TBW. The highest measured increases of TBW at an altitude of 1000 meters above sea level was from 1.7 to 2.1 litres. Both 


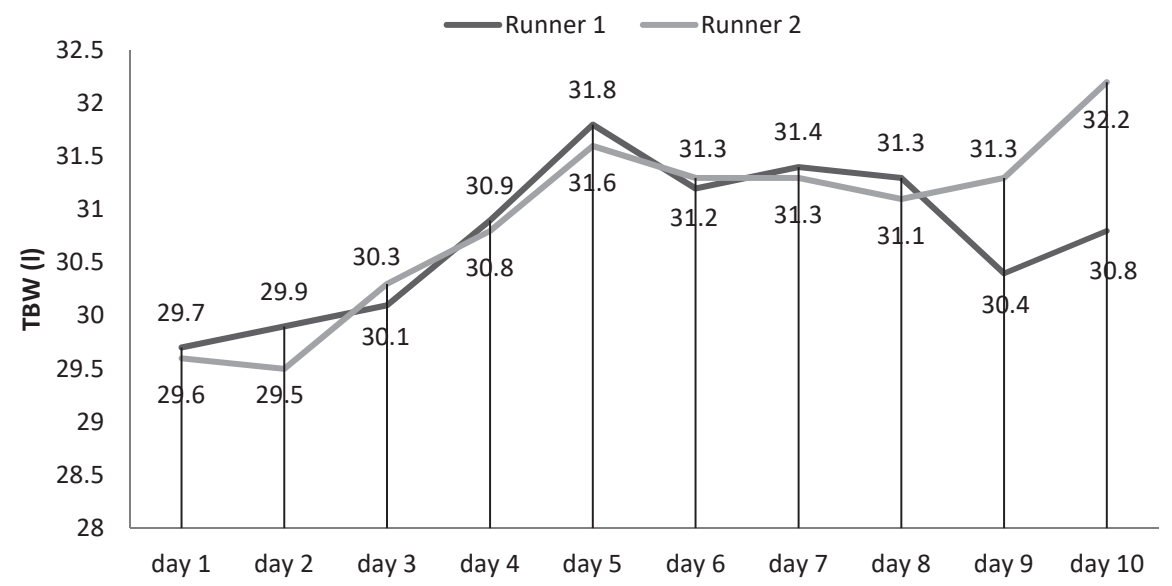

Figure 1 The course of changes in TBW at an altitude of 1000m (Czech Republic) Note: $P \leq 0.04$, Num $=10$ (Retention Peak, 5th day)

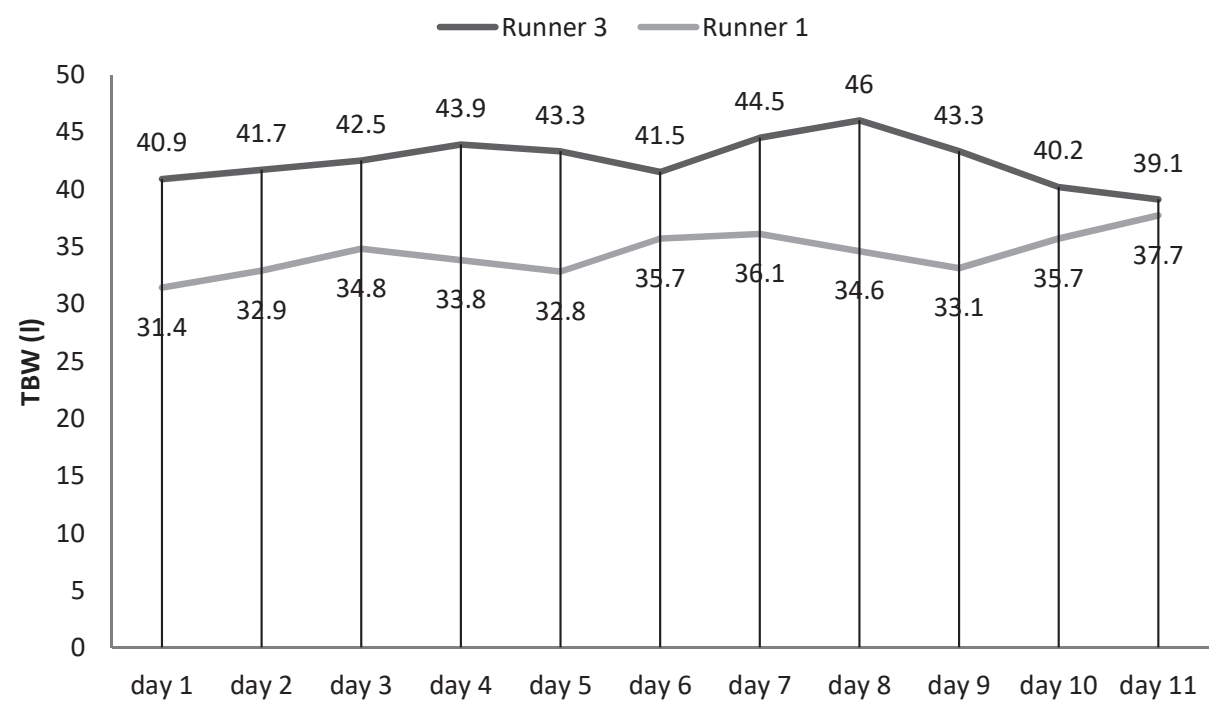

Figure 2 The course of changes in TBW at an altitude of $1770 \mathrm{~m}$ (Morocco) Note: $P \leq 0.04$, Num $=11$ (Retention Peak, 8 th or 11th day)

tested runners reached a peak of retention on the 5th day of stay. Similarly, in the second half of the same camp, the tested runners' curves showed a propensity to maintain an increase in TBW.

At an altitude of $1770 \mathrm{~m}$ above sea level runner 1 reached an increase of TBW of 6.3 litres, with a retention peak on the 11th day, and runner 3 had an increase of 5.1 litres, with a peak on the 8th day. Runner 3 had a lower TBW at the end of the camp than when they had arrived. We believe that individual differences between runners could be probably caused by gender or vegetarianism. 


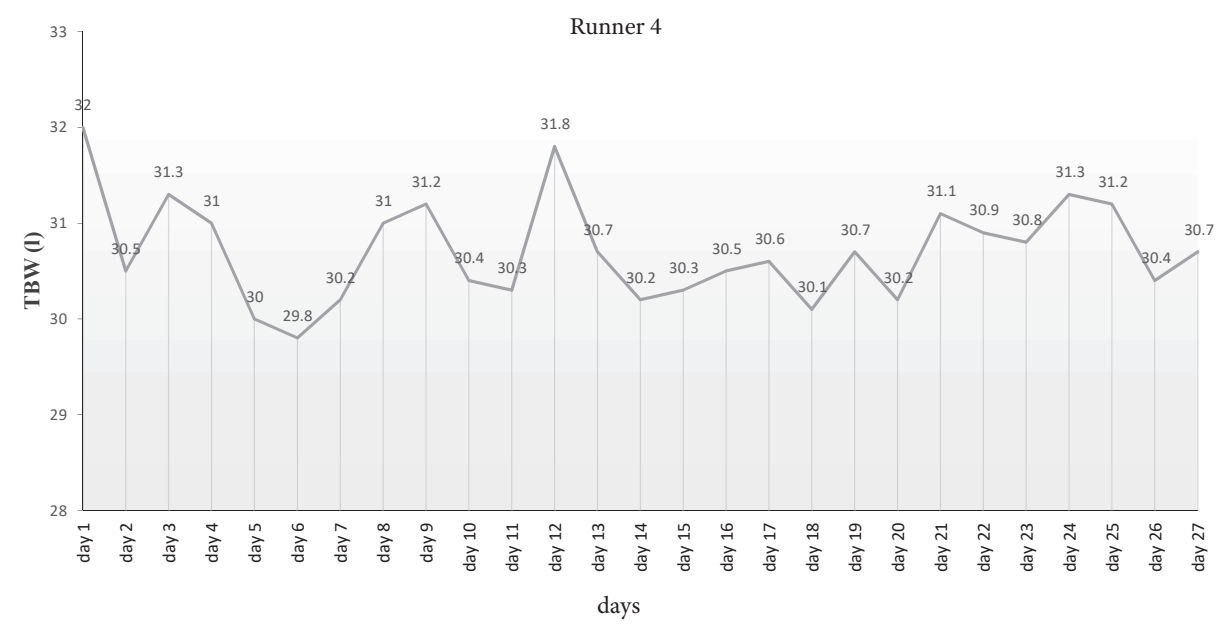

Figure 3 The course of changes in TBW at an altitude of $2750 \mathrm{~m}$ (Ethiopia) Note: $P \leq 0.04$, Num $=27$ (Retention Peak, 12th day)

For runner 4 at $2700 \mathrm{~m}$ above sea level the TBW decline occurred at the beginning of the camp, and she returned to the original value on the 12th day of stay. Then the decline occurred again, with a gradual rise to the 24th day of stay, which was again followed by a decline. Considering the course of TBW changes, this day (12th) is considered a retention peak. The higher value from the first measurement is considered a consequence of travel. In the overall context a TBW decrease in absolute terms of 1.25 litres was recorded compared to the situation at the beginning of camp.

\section{DISCUSSION}

Changes in the distribution of TBW reflect progress of acclimatization. In practice, this means that data monitoring of TBW can individualize the process of acclimatization and adaptation to training load at high altitude. Our pilot study confirmed the relationship of the current acclimatization and distribution of TBW. The number of days when retention peaks of TBW were achieved corresponded with higher levels of altitude. From this perspective we can say that progress of TBW ( $p \leq 0.04$, effect size-medium, 0.77) indicated completion of acclimatization (Cohen, 1992).

Within the context of our general knowledge about mountain stays, where the literature suggests rather threatening dehydration (losses increased by ventilation and the excretion of urine) it shows that all athletes were well hydrated and the question is whether water retention is an indicator of the acclimatization process, or, conversely, lack of training process and therefore losses of water during physical exercise (Noakes, 2003; Basset \& Howley, 2000; Lungby, 2012; Billat et al., 2003; Bunc, 2012; Saunders et al., 2004; Green et al., 2000; Legrand, 2005). Generally, in the acclimatization phase, we observed two critical periods: 4th-6th day of a stay, and 10th-12th day of stay (Gore et al., 2001; Green et al., 2000; Lungby, 2012; Saunders et al., 2004; Wilber, 2004). From this perspective, the measurement results show that the retention peaks 
in runners 1, 2, and 3 fall within these periods. For runner 4, who attended camp at a higher altitude, the situation is more complicated because there were fluctuations in the content of TBW in the range of 1-2 litres, with the highest depression on day 5 and then again a gradual rise, reaching a maximum on the 10th day, when she returned almost to the initial value. Kinetics TBW corresponded with the theoretical, expert assumptions on critical days during endurance training at high altitudes (Noakes, 2003; Wilber, 2004). We can therefore conclude that the kinetics of TBW can be used for indication during the acclimatization.

Although there are not so significant fluctuations (in the range of $6.25 \%$ ), the results of the onset of retention peaks agree with the general findings and also with the results of runners 1,2 , and 3 . We believe, therefore, that changes in TBW could be one of the biomarkers which affect the acclimatization process. Conversely, a big effort to accelerate the adaptation may adversely affect the course of acclimatization. It can be assumed that even better results would be obtained by measuring not only TBW, but also extracellular and intracellular water, which would allow the precise assessment of the movement of water within the organism, which, for example, may affect the value of hematocrit (Wilber, 2004; Saunders et al., 2004; Julian, 2003; Legrand, 2005; Levine et al., 2005). The course of TBW changes for runner 4 could be more influenced by the training process than runners 1,2, and 3. A larger role in altitude $2700 \mathrm{~m}$ above sea level could be played by external conditions (climate, wind, total fluid intake of the athlete, the presence of food in the digestive tract, the saturation of the muscles with carbohydrates, women's premenstrual phase and finally a clearly demonstrated link with ethnicity (Gore et al., 2001; McCully \& Hamaoka, 2000; Legrand, 2005).

\section{CONCLUSION}

Based on the monitoring of changes in TBW at higher altitudes during the preparation of elite runners we can conclude that the measuring of changes in TBW during training camps at higher altitudes may be one of the biomarkers during acclimatization. In the expert literature, the issue of acclimatization is associated with dehydration. Excessive increases in TBW by the organism can slow down acclimatization. The results of our study correspond with the findings of previous researchers on critical days during the stay of elite runners at higher altitudes. Retention peaks were reached in the periods that correspond with acclimatization "crisis-depression performance", as reported in the literature (Billat et al., 2003; Lungby et al., 2012; Neaumann et al., 2005). Given that the group consisted of only four participants and was not fully homogeneous, we interpret the data as significant $(\mathrm{p} \leq 0.04)$ with medium effect size $(0.77)$.

A promising direction for future research is suggested as further follow-up of ECW and ICW.

\section{REFERENCES}

Alonso, J. (2004). Methods to increse the delivery of oxygen New studies in Athletics, 19, 33-43.

Arrese, A., Izquierdo, D. M., \& Urdiales, D. M. (2005). A review of the maximal oxygen uptaken values necessary for running performance levels. New Studies in Athletics, 20(3), 7-20. 
Basset, D., \& Howley, E. T. (2000). Limiting factors for maximum oxygen uptake and determinants of endurance performance. Med. Sci. Sports Exerc., 32(1), 70-84.

Billat, V., Lepretre, P. M., Heugas, A. M., Laurence, M. H., Salim, D., \& Koralstein, J. P. A. (2003). Training and bioenergetic charakteristic in elite male and female Kenyan runners. Med. Sci. Sports Exerc., 35(2), 297-304.

Bragada, J. A. (2010). Longitudinal study in $3000 \mathrm{~m}$ male runners: relationship betwen performance and selected physiological parameters. Journal of Sports Science Medicine, 9(3), 439-444.

Bunc, V. (2012). Diagnostika ve sportu. Trenér biatlonu, 1-17.

Bunc, V. (2016). Obesity - Causes and Remedies. Physical Activity Rewiew, 4, 55-56.

Bunc, V., \& Skalská, M. (2012). Funkční a pracovní charakteristiky zdravotnických záchranářů. Česká kinantropologie, 16(3), 89-100.

Cohen, J. (1992). A power primer. Psychological Bulletin, 112(1), 155-159.

Deurenberg, P., Deurenberg-Yap, M., \& Schouten, F. J. (2002). Validity of total and segmental impedance measurements for prediction of body composition across ethnic population groups. European Journal of Clinical Nutrition, 56(3), 214-220.

Dovalil, J., et al. (2000). Sportovni výkon a trénink ve vy̌̌ši nadmořské výšce. Prague: Český olympijský výbor, Fakulta tělesné výchovy a sportu Univerzity Karlovy, Olympia.

Fuchs, U., \& Reiss, M. (1990). Höhentraining das Erfolgskonzept der Ausdauersportarten (Trainerbibliotek 27). Münster: Philippka Verlag.

Gore, C., Hanhn, A. G., Aughey, R. J., Martin, D. T., Ashenden, M. J., \& Clark, S. A. (2001). Live high: train low increases muscle buffer capacity and submaximal cycling efficiency. Acta Physiol. Scand., 173(3), 275-286.

Green, H., Roy, B., Grant, S., Hughson, R., Burnett, M., \& Otto, C. (2000). Increase in submaximal cycling efficiency mediated by altitude acclimatization. J. Appl. Physiol., 89(3), $1189-1197$.

Hamar, D. (1996). Fyziologické a biochemické aspekty rozvoja vytvalostných schopností. In: Teoretické a metodické problémy súčasnej atletiky (pp. 4-12). Bratislava: FTVŠ UK.

Julian, G. (2003). Intermittent normobaric hypoxia does not alter performance or erythropoetic markers in highly trained distance runners. J. Appl. Physiol., 96(5), 1800-1807.

Katyama, K., Matsuo, H., Ishida, K., Mori, S., \& Miyamura, M. (2003). Intermittent hypoxia improves endurance performance and submaximal exercise efficiency. High Alt. Med. Biol., 4(3), 291-304.

Kučera, V., \& Truksa, Z. (2000). Běhy na střední a dlouhé tratě. Prague: Olympia.

Kushner, R. (1992). Bioelectrical impedance analysis: A rewiew of principles and applications. Journal of the American College of Nutrition, 11(2), 199-209.

Lean, M., Han, T. S., \& Deurenberg, P. (1996). Predicting body composition by densitometry from simple anthropometric measurement. Am. J. Clin. Nutr., 63(1), 4-14.

Legrand, R., et al. (2005). O2 arterial desaturation in endurance athletes increase muscle deoxygenetion. Med.Science in Sports Exerc., 37(5), 782-788.

Levine, B., \& Stray-Gundersen, J. (2005). Point: positive effects of intermittent hypoxia (live high: train low) on exercise performance are mediated primarily by augmented red cell volume. J. Appl. Physiol., 83(1), 102-112.

Liška, J., \& Písařík, M. (1985). Běhy na střední a dlouhé tratě. Prague: ÚV ČSTV.

Lungby, C., Millet, G. P., \& Calbet, J. A. (2012). Does altitude training increase exercise performance in elite athletes? Br. J. Sports Med., 46(11), 792-795.

Malina, R., Bouchard, C., \& Bar-Or, O. (2004). Growth maturation and physical activity (2nd edition). Champaign, IL: Human Kinetics.

McCully, K., \& Hamaoka,T. (2000). Near-enfrared Spectroscopy: What can it tell us about oxygen saturation in skeletal muscle? Exerc. Sport Sci. Rev., 28(3), 123-127. 
Morrison, E., \& Cooper, P. D. (2006). Some Bio-Medical Mechanismus in Athletic Prowess. West Indian Medical Journal, 55(3), 205-209.

Neumann, G., Pfützner, A., \& Hottenrott, K. (1993). Alles unter Kontrolle. Aachen: Meyer \& Meyer.

Neumann, G., Pfützner, A., \& Hottenrott, K. (2005). Trénink pod kontrolou. Prague: Grada Publishing.

Noakes, T. (2003). Lore of Running (4th edition). Champaign, IL: Human Kinetics.

Pařízková, J. (1998). Složení těla, metody měření a využití ve výzkumu a lékařské praxi. $M e$ dicina Sportiva Bohemica et Slovaca, 7(1), 1-6.

Písařík, M., \& Liška, J. (1985). Běhy na střední a dlouhé tratě. Prague: ÚV ČSTV Sportpropag.

Pupiš, M., \& Korčok, P. (2007). Hypoxia jako súčast športovej př́pravy. Banská Bystrica: Univerzita Mateja Bela, FHV.

Reiss, M., \& Meinelt, K. (1985). Erfahrungen, Probleme und Konsequenzen bei der Erhöhung der Wirksamkeit der Steurung und Regelung des Hochleistungstrainings. Theorie und Praxis Leistungssport (Leipzig), 23, 26-50.

Saunders, P., Telford, R. D., Pyne, D. B., Cunnigham, R. B., Gore, C. J., Hahn, A. G., \& Hawley, J. A. (2004). Improved running economy in elite runners after 20 days of simulated moderate - altitude exposure. J. Appl. Physio., 96(3), 931-937.

Seunghoon, C. (2001). A New Method for BIA. Research thesis based on InBody. Biospace.

Sherry, E., \& Wilson, S. F. (1998). Oxford handbook of sports medicine. Oxford: University Press.

Suchý, J., et al. (2012). Fáze adaptace na vyšší nadmořskou výšku. In: J. Suchý, Využití hypoxie a hyperoxie ve sportovním tréninku (pp. 42-43). Prague: Karolinum.

Suchý, J., et al. (2014). Trénink ve vy̌̌ši nadmořské výšce. Prague: Mladá fronta.

Thomas, B., Cornish, B. H., \& Ward, L. C. (1992). Bioelektrical Impedance Analysis for Measurement of Body Fluid Volumes: a Review. Journal of Clinical Engineering, 17(6), 505-510.

Weineck, J. (1998). Optimales Training. Balingen: Spitta Verlag GmbH.

Wilber, L. (2004). Altitude Training and Athletics Performance. Champaign, IL: Human Kinetics. 